\title{
Beleza é fundamental?
}

Tecnologia e estética do racismo: ciência e arte na política da beleza.

FLORES, Maria Bernadete Ramos.

Chapecó: Argos, 2007. 452 p.

Já faz algum tempo que estamos estranhando a importância exagerada que assumem o corpo e a sexualidade não só em nossas festas de carnaval, mas também no imaginário social. Nos discursos históricos sobre o povo brasileiro, mulheres sensuais e homens vorazes logo ganham destaque, especialmente quando se discute a construção da identidade nacional. Nos textos de intelectuais como Paulo Prado e Gilberto Freyre, nos anos 20 e 30, ou retroce-dendo aos livros dos viajantes europeus, que aqui aportaram nos séculos XVII e XVIII, ou mesmo voltando ao texto inaugural, a carta de Pero Vaz de Caminha para el Rey do Império português, os corpos ganham destaque a partir de um olhar que sensualiza as formas, erotiza os gestos, mas também classifica, normatiza e condena. É assim que as "índias nuas" se tornam próximas da "moura encantada" em Freyre, libidinosas, excitáveis e prontas a entregaremse aos colonizadores portugueses, segundo Prado, em meio à promiscuidade sexual reinante no período colonial, participando como figuras 
centrais de representações misóginas repetidas por décadas a fio.

Diante desse quadro mórbido e assustador, a preocupação com o "saneamento da raça" e com a produção de um povo higiênico, saudável, limpo e belo emerge especialmente nos textos dos médicos e juristas, desde o século XIX, e adquire toda a centralidade nas discussões dos eugenistas, a tal ponto que Renato Kehl, principal expoente da eugenia no Brasil, publica um longo volume intitulado $A$ cura da fealdade, em 1923, preocupado com as aparências de um povo que, aos seus olhos, parecia muito feio.

A perplexidade que esse texto produz, principalmente ao se considerar o prestígio atual das belíssimas modelos brasileiras em todo o mundo, levou a historiadora Maria Bernadete Ramos Flores, professora titular do Departamento de História da Universidade Federal de Santa Catarina, a percorrer minuciosamente os estranhos caminhos das discussões tecidas pelos homens e mulheres cultos, no Brasil, desde o século XIX, referenciados pelas teorias racistas européias. O resultado é um denso e elaborado estudo intitulado Tecnologia e estética do racismo: ciência e arte na política da beleza, que vem a público numa edição cuidadosa, pela Editora Argos.

Na política racista de domesticação dos corpos e produção de indivíduos belos, mostra a autora, o desenvolvimento científico e tecnológico alia-se às projeções artísticas inspiradas desde a Grécia antiga. Historiadora perspicaz, Maria Bernadete evidencia como o culto ao corpo belo dos antigos é apropriado e subvertido na Modernidade, tornando-se sujeição aos padrões dominantes de existir, da aparência à subjetividade. Pedagogia dos corpos, educação dos sentidos, autocontrole $e$ pouca expressividade emocional são temas que constituem um amplo repertório das práticas da dominação. Leitora de Michel Foucault, para além de outras importantes referências filosóficas, a autora mostra como, para além das mentes, o poder incide sobre os corpos, os gestos e as individualidades, ameaçando capturar a própria vida.

Desde a primeira parte do livro, intitulada "Ciência e arte na políica da beleza", passando por "A questão sexual" e "A invenção da raça", terceira e quarta partes, é a beleza do corpo que está em jogo. Mas de que beleza se trata? Que políticas se constituem para atingir esse ideal que se quer eterno e universal e que, não obstante, a autora demonstra sobejamente ser histórico? Os tratados de sexologia de médicos como o Dr. Hernani de Irajá, autor de Morpholgia da mulher: a plástica feminina no Brasil, em quarta edição, em 1937 (p. 104), e Sexo e beleza (p. 109), por exemplo, discutem a fisiologia do corpo feminino, informam sobre as necessidades sexuais masculinas e condenam a prostituição e a homossexualidade, revelando um medo atávico da degenerescência física e moral. Maria Bernadete examina minuciosa e ironicamente a obra científica e a artística desse médico, que é também pintor e que, como tal, se diz contrário a toda expressão das vanguardas artísticas, revelando que o ideal de beleza feminina expresso numa e noutra obra não se diferencia, atravessado pelos mesmos preconceitos e pelo mesmo regime de verdades e valores morais.

Trabalhando com a categoria feminista do gênero, a autora não se restringe às questões femininas. Nesse sentido, destaca como, obcecados com a higienização de todo o povo brasileiro, com o branqueamento da raça e com a domesticação das mulheres, os doutores também definem o corpo masculino belo, enquanto estigmatizam o seu oposto, o do homem pobre, feio e "preguiçoso". Assim, "anormais" masculinos ou femininos passam a habitar inúmeras páginas desse livro, através dos discursos das elites, polarizando com os ideais de pureza e limpeza. Autoritárias, estas entendem que embelezar toda uma população implica corrigir e adestrar os diferentes, para torná-los um todo homogêneo e coeso à imagem do Homem. Como afirma Kehl, "O homem capaz de talhar no mármore a Vênus, é capaz também de moldar plasticamente toda a humanidade" (p. 62).

$\mathrm{O}$ que se quer como melhoria do povo resulta em pedagogia totalitária da população, em biopolíticas, pode-se acrescentar. Em sua ficção de 1945 intitulada O presidente negro ou o choque das raças: romance americano do ano 2228, Monteiro Lobato propõe a esterilização dos negros como método radical para branquear a raça, entendendo como possível "o conserto do mundo pela eugenia", como nos mostra a autora (p. 410). "Se a cultura deriva da raça e do meio, ou vice-versa, é inútil esta natureza dionisíaca brasileira, já que falta ao Jeca a disciplina apolínea para criar a vida, a arte, a cultura, o progresso, a técnica, 0 pensamento racional", parafraseia ela, ironizando o discurso masculino racista.

Lobato, porém, não é exceção à regra. Nem mesmo o feminismo liberal entra em dissonância com esse ideário nacionalista e 
racista. Em 1929, a utopia da advogada e escritora paulista Adalzira Bittencourt, apresentada em seu romance Sua Excia: a presidente da república no ano de 2500, imagina um Brasil grandioso, moderno, racionalmente organizado, branco e asséptico. Governado por uma mulher, não é menos autoritário e racista, como deixa bem claro a historiadora que, sem abandonar o feminismo, não faz concessões em suas críticas contundentes. Nesse país imaginário, em que as mulheres estariam no poder, sem deixar de cumprir a "sagrada" missão materna, os negros seriam devolvidos à África e a pobreza seria eliminada, tanto quanto a feiúra. "A estética tomou conta de tudo! Toda feiúra fora removida! Não só as pessoas se tornaram belas. As cidades eram as mais modernas do mundo, sob a atuação das engenheiras", ironiza a autora à página 415.

Livro erudito, Tecnologia e estética do racismo... investiga com cuidado cada tema, por sua vez desdobrado em múltiplas temáticas e referências que enriquecem em grande parte a produção que se vem realizando no interior da História Cultural. Menos voltada para a análise das lutas sociais entre as classes, essa historigrafia introduz novos temas e permite novas abordgens, descortinando as manifestações do poder lá onde menos se espera, nas práticas discursivas, no corpo, na sexualidade, nos sonhos ou nas fantasias.
A leitura desse excelente trabalho nos leva a perguntar pelas razões históricas de tanto incômodo diante da feiúra, tanto quanto sugere um estranhamento pelo modo como a beleza foi naturalizada e associada a ideais autoritários, racistas e eugênicos, tão distantes daquilo que valorizavam os antigos gregos e romanos. Talvez se possa dizer que se trata aqui de uma história do impossível, se perguntarmos como tudo isso foi possível, como essas concepções tão excludentes e hierarquizadoras ganharam crédito e tornaram-se hegemônicas em toda, ou quase toda a sociedade, repetidas como verdades, sem maiores questionamentos.

E mais, leva-nos a perguntar pela sua continuidade e desdobramentos em nossos dias, quando a "ditadura do corpo e da beleza" deixa de atingir apenas as mulheres, exigindo esbeltez, agilidade, flexibilidade e adequação aos novos padrões estéticos também dos homens, heterossexuais, gays, negros, brancos, orientais, jovens e velhos. O crescimento das academias de ginástica, dos programas de body health, das dietas e receitas de reeducação alimentar e da cirurgia plástica está aí, mostrando que o espaço público se torna uma grande passarela, onde a exigência número um para a aceitação e o sucesso é a própria expressão corporal. Mais uma volta no parafuso?

Margareth Rago Universidade Estadual de Campinas 